С.Г. Леушин ${ }^{1}$, О.В. Бєсова ${ }^{1}$, М.М. Олещук ${ }^{2}$

${ }^{1}$ Харківський національний університет Повітряних Сил ім. І. Кожедуба, Харків

${ }^{2}$ Військова частина А 2533, Дніпро

\title{
ЕКСПЕРИМЕНТАЛЬНІ ДОСЛІДЖЕННЯ НЕНАВМИСНИХ АКТИВНИХ ПЕРЕШКОД ДЛЯ ПРИЧОРНОМОРСЬКОГО РЕГІОНУ, ДЖЕРЕЛО ЯКИХ ЗНАХОДИТЬСЯ ЗА МЕЖЕЮ РАДІОГОРИЗОНТУ У ДЕЦИМЕТРОВОМУ ДІАПАЗОНІ ХВИЛЬ
}

Дослідження фізичних процесів над акваторіями морів свідчать про те, що зміни клімату збільшують вірогідність появи ТРХ над морем. Тому зростає вірогідність появи АП, які діють за межами радіогоризонту. Процеси, що відбуваються в прибережних районах і над морем нестаціонарні, тому параметри АП, які діють за межсами радіогоризонту, істотно змінюються. Однак при цьому зростає вплив ненавмисних активних перешкод (АП), джерело яких знаходиться за межею радіогоризонту. Причиною цього вважають стан радіофізичних характеристик тропосфери над морською поверхнею. Експериментальні дослідження, проведені в ХНУПС дозволили отримати характеристики ненавмисних АП, які можуть виникати при існуванні ТРХ. Досвід експлуатації РЛС, які розміщені поблизу Чорного та Азовського морів показує, що дальність поширення електромагнітних хвиль (ЕМX) при наявності ТРХ може суттєво перебільшувати дальність щодо радіогоризонту. Для кожної РЛС ЕМС визначається окремо. Тому необхідно дослідити АП для кожної позиції РЛС приморського розміщення.

Ключові слова: ненавмисні активні перешкоди, тропосферний радіохвилевод, експериментальні дослідження, тропосфера.

\section{Вступ}

Постановка проблеми. Сучасний розвиток науки i технологій дозволяє активно використати останні досягнення в засобах повітряного озброєння. Наприклад, має розвиток застосування БЛА розвідки та знищування об'єктів різного призначення [1]. БЛА мають малі розміри (ЕПР), різні швидкості та висоту польоту. Тому для їх радіолокаційного вияву та наведення засобів знищення потрібна побудова спеціальних систем. Для таких РЛС у прибережному регіоні необхідна додаткова оцінка їх електромагнітної сумісності (ЕМС) з радіотехнічними системами (РТC), які знаходяться за межею радіогоризонту.

Аналіз останніх досліджень і публікацій. Військові конфлікти останніх років свідчать про зростаючу роль засобів безпілотного повітряного нападу (БЛА) при нанесенні ударів по найбільш важливих об'єктах державного і військового призначення. У районі водойм БЛА звичайно здійснюють нальоти з боку водойм на малих та гранично малих висотах.

Пошук шляхів збільшення дальності вияву БЛА веде до необхідності використання тропосферних радіохвилеводних каналів поширення електромагнітних хвиль. У цих умовах локація БЛА здійснюється в умовах специфічних перешкод [12-13].
Стаття присвячена результатам дослідження ненавмисних активних перешкод (АП), джерелом яких $\epsilon$ випромінювання побутових РТС, що розповсюджуються за межі горизонту по тропосферному радіохвилеводу (ТРХ).

Досвід експлуатації РЛС, які розміщені поблизу Чорного та Азовського морів та показує, що дальність поширення електромагнітних хвиль (ЕМХ) при наявності ТРX може суттєво перебільшувати дальність щодо радіогоризонту.

Однак при цьому зростає вплив ненавмисних активних перешкод (АП), джерело яких заходиться за межею радіогоризонту [2-3]. Причиною цього вважають стан радіофізичних характеристик тропосфери над морською поверхнею [8]. Експериментальні дослідження, проведені в ХУПС [5-6] дозволили отримати характеристики ненавмисних АП, які можуть виникати при існуванні ТРХ.

Мета статті - оцінка результатів дослідження ненавмисних активних перешкод дециметрових РЛС приморського базування, джерело яких знаходиться за межею радіогоризонту.

\section{Виклад основного матеріалу}

Як відомо, основним засобом забезпечення ЕМС радіоелектронних засобів (РЕЗ) $є$ частотнотериторіальне рознесення РТС, які знаходяться у межі радіогоризонту [2]. 
Але, відмінність умов поширення ЕМХ від стандартних, що відбувається в приморських районах, може призводити до невиконання умов EMC [6].

Для кожної РЛС ЕМС визначається окремо. Тому необхідно дослідити АП для кожної позиції РЛС приморського розміщення.

Дослідження фізичних процесів над акваторіями морів [12-13] свідчать про те, що зміни клімату збільшують вірогідність появи ТРХ над морем. Тому зростає вірогідність появи АП, які діють за межами радіогоризонту [5]. Метеорологічні процеси і явища, при яких можливе утворення ТРХ детально описані в $[2 ; 9]$.

Процеси, що відбуваються в прибережних районах і над морем нестаціонарні, тому параметри АП, які діють за межами радіогоризонту, істотно змінюються [4].

Для дослідження АП, які діють за межами радіогоризонту було розроблено лабораторний апаратно-вимірювальний комплекс (АПК) [10].

АПК складався з типових пристроїв:

1. Приймальної антени DA3000;

2. Радіоприймача (РП) AR5000;

3. Персональної електронної обчислювальної машини (ПЕОМ);

4. Постійного запам'ятовуючого пристрою.

Структурна схема АПК приведена на рис. 1.

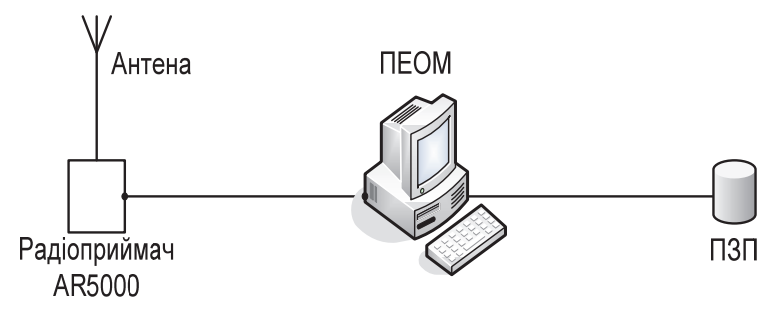

Рис. 1. Структурна схема АПК Джерело: [2, С. 9].

Приймальна антена (DA3000) - широкосмугова диско-конусна антена, яка призначена для проведення спеціальних досліджень.

Ïї технічні характеристики наведено у табл. 1.

Таблиця 1

Технічні характеристики антени DA3000

\begin{tabular}{|l|c|}
\hline \multicolumn{1}{|c|}{ Діапазон частот } & $25-2000$ МГц \\
\hline $\begin{array}{l}\text { Діаграма } \\
\text { спрямованості }\end{array}$ & кругова \\
\hline Хвилевий опір & 50 Ом \\
\hline Висота & 1700 мм \\
\hline $\begin{array}{l}\text { Вертикальна } \\
\text { поляризація }\end{array}$ & вертикальна \\
\hline
\end{tabular}

Джерело: [2, С. 15].
Радіоприймач (AR5000) - стаціонарний професійний широкодіапазонний багатофункціональний радіоприймач виробництва компанії AOR.

Основні параметри (AR5000):

1) діапазон частот від 10 кГц до 2600 (МГц);

2) крок настройки 1 (Гц);

3) чутливість $-10 \ldots-12$ (дБ).

ПЕОМ - типова.

Технічні характеристики ПЕОМ наведено у табл. 2.

Таблиця 2

Основні технічні характеристики

ПЕОМ

\begin{tabular}{|l|l|}
\hline Тип процесору & AMD Duron \\
\hline $\begin{array}{l}\text { Тактова частота } \\
\text { процесору }\end{array}$ & 750 МГц \\
\hline $\begin{array}{l}\text { Об’єм оперативної } \\
\text { пам'яті }\end{array}$ & $128 \mathrm{MB}$ \\
\hline Материнська плата & Gigabyte 7ZM \\
\hline Аудіо підсистема & AC'97 \\
\hline $\begin{array}{l}\text { Аналого-цифровий } \\
\text { перетворювач }\end{array}$ & AD1881A \\
\hline
\end{tabular}

Джерело: [2, С. 6].

АПК було розміщено на узбережжі Чорного моря поблизу м. Одеса.

Як джерела активних перешкод (АП), що поширюються за межі радіогоризонту, були обрані передавальні станції теле- і радіомовлення Туреччини та Болгарії, що працюють в діапазоні частот від 100 МГц до 1 ГГц і розташовані на узбережжі Чорного моря, протилежному розміщенню АПК.

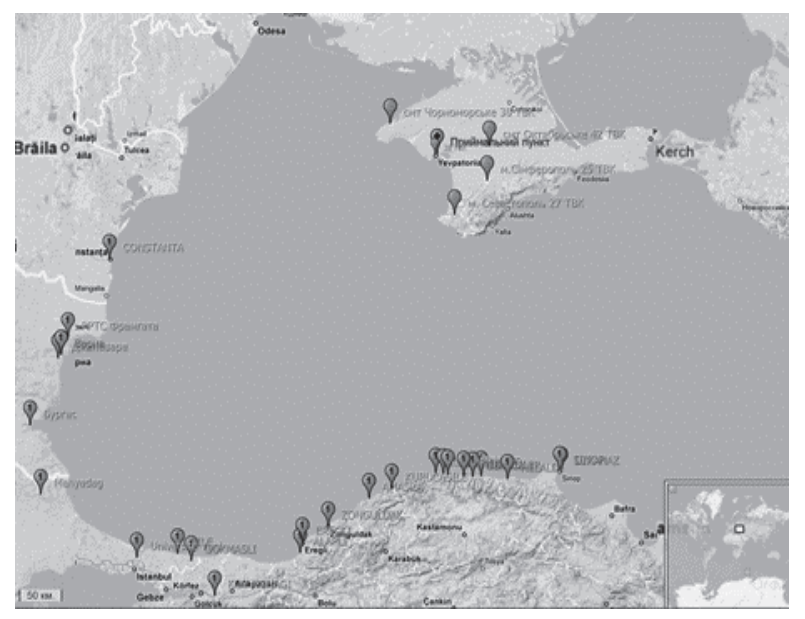

Рис. 2. Розміщення джерел можливих АП над Чорним морем за межами радіогоризонту Джерело: [12, С. 18].

Робота таких радіоцентрів цілодобова (в більшості випадків), що дозволяє відзначати появу ТРХ [4-5].

На рис. 2 показано розташування можливих джерел АП в Чорноморському регіоні. 
Як видно з рис. 2, джерела випромінювання АП знаходяться далеко за межами прямої видимості 350...601 (км) і традиційними механізмами пояснити таку дальність поширення ЕМХ неможливо.

Аномально велика дальність поширення ЕMX за межі горизонту можлива при наявності TPX [2-4].

Кожний радіоцентр має окрему основну смугу частот.

Смуги частот радіоцентрів не перетинаються. Однак, крім основного випромінювання кожний 3 радіоцентрів передає в ефір неосновні випромінювання, що призводить до виникнення додаткових АП та до перетинання їх амплітудо-частотних спектрів (АЧС).

Дальність від джерел АП до приморських РЛС становить $350 \ldots 601$ (км), а їх потужність $5 \ldots 12,5$ (кВТ).

Потужність АП на вході АПК при хвилеводному поширенні ЕМХ може становити від 0,001мВт до 10мВт (в залежності від пори року і часу доби). Максимальна потужність АП при наявності ТРХ мала місце після сходу і заходу сонця в кінці липняна початку вересня та у ясну погоду при малому хвилюванні моря.

При звичайному поширенні ЕMX потужність АП на вході АПК може становити 0,005 ... 1,0 (мкВт) та не залежить від пори року і часу доби. Максимальна потужність АП при звичайному поширенні EMX мала місце у похмуру погоду та при малому хвилюванні моря.

Через розбіжності довжини променів в ТРХ, що приходять від окремих джерел АП до АПК, має місце інтерференція, яка призводить до завмирань АП за часом і до федингу по частоті. В умовах, коли різниця ходу променів змінна з'являються флуктуації амплітуд АП [4-5].

Це призводить до того, що АЧС ненавмисних АП стає майже суцільним та має лише максимуми на окремих частотах.

На рис. 3 наведено типову часову структуру АП на вході приймача АПК.

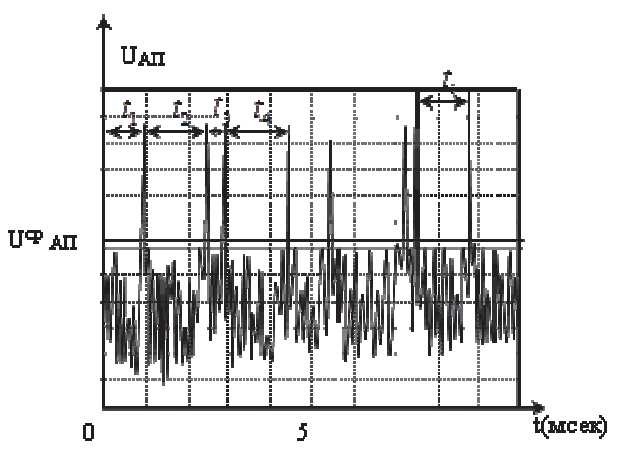

Рис. 3. Типова часова структура АП на вході приймача АПК

На рис. 4 наведено типовий АЧС АП на вході приймача АПК. Для обох рисунків час спостереження було обрано 10 (мсек).

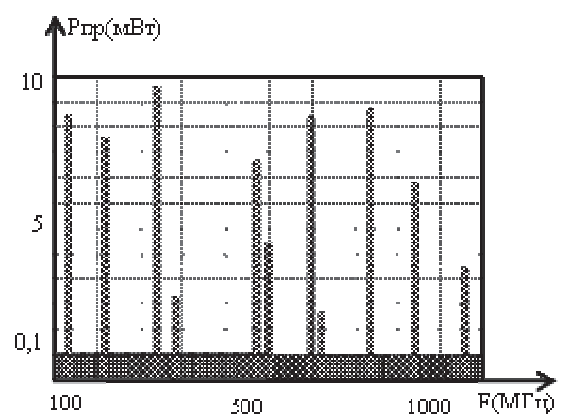

Рис. 4. Типовий АЧС АП на вході приймача АПК Джерело: [13, С. 32].

\section{Висновки}

Процеси, що відбуваються в прибережних районах і над морем нестаціонарні, тому параметри активних перешкод, які діють за межами радіогоризонту, істотно змінюються. Для причорноморських РЛС дециметрового діапазону хвиль ненавмисні активні перешкоди, які діють за межами радіогоризонту, можуть вважатися додатковим нестаціонарним широкосмуговим шумовим фоном, який має вузькосмугові складові. Це призводить до того, що АЧС ненавмисних активних перешкод стає майже суцільним та має лише максимуми на окремих частотах.

\section{Список літератури}

1. Довідник учасника АТО: озброєння і військова техніка Збройних сил Російської Федерації / А.М. Алімпієв, Г.В. Пєвцов, Д.А. Гриб та ін. / За заг. ред. А.М. Алімпієва. - Х.: Оригінал, 2015. - 732 с.

2. Скольник М. Справочник по радиолокации / М. Скольник. - Нью-Йорк, 1970. Перевод с англ. (в четырех томах). - М.: Сов. радио, Т1 - 1976. - 456 с.; Т2 - 1977. - 408 с.; Т3 - 1979. - 528 с.; Т4 - 1978. - 376 с.

3. Теоретические основы радиолокации / Под ред. Я.Д. Ширмана. - М.: Сов. радио, 1970. - 560 с.

4. Деякі аспекти локації маловисотних цілей за межами дальності прямої видимості над морем / В.Д. Карлов, О.К. Шейгас, Є.О. Меленті, В.М. Петрушенко // Системи обробки інформації. - 2013. - № 1(108). - С. 66-69.

5. Про вплив механізму розповсюдження радіохвиль на локацію цілей в тропосферному радіохвилеводі над морем / В.Д. Карлов, О.В. Бєсова, М.М. Олещук, М.М. Петрушенко // Х наукова конференція Харківського університету Повітряних Сил ім. І. Кожедуба “Новітні технології - для захисту повітряного простору”. - Харків, 9-10 квітня 2014 р. - C. 254. 
6. Карлов В.Д. Статистичні характеристики радіолокаційних сигналів відбитих від місцевих предметів в умовах аномальної рефракції / В.Д. Карлов, А.О. Родюков, І.М. Пічугін // Наука і техніка Повітряних Сил Збройних Сил України. -2015 . - № 4(21). - С. 71-74.

7. Бартон Д. Радиолокационное сопровождение целей при малых углах места / Д. Бартон // Труды Института инженерии по электротехнике и радиоэлектронике. - 1974. - № 6. - C. 37-61.

8. Dax P.R. Keep track of than low-flying attack / P.R. Dax // Microwaves. - 1976. - № 15. - P. 36-53.

9. Разсказовский В.Б. Радиолокационное сопровождение маловысотных целей над поверхностью моря / В.Б. Разсказовский // Радиофизика и электроника. - 2006. - № 3(11). - С. 377-384.

10. Nebabin V.G. Methods and Techniques of Radar Recognition / V.G. Nebabin. - Boston-London: Artech House, 1994. $-273 \mathrm{p}$.

11. Komarov I.V. Fundamentals of short-range FM radar / I.V. Komarov. - Norwood: Artech House, 2003. - 289 p.

12. Результати експериментальних досліджень коефіцієнта рефракції у континентальній частині України/ і.Г. Леонов, А.М. Коржов, А.С. Присяжний, Р.М. Животовський // VIII наукова конференція Харківського університету Повітряних Сил ім. І. Кожедуба “Новітні технології - для захисту повітряного простору”. - Харків, 18-19 квітня 2012 р. - C. 304.

13. Леонов И.Г. Множественные активные помехи в РТС приморского базирования и борьба с ними / И.Г. Леонов, А.Н. Коржов, Р.М. Животовский // IX наукова конференція Харківського університету Повітряних Сил ім. I. Кожедуба “Новітні технології - для захисту повітряного простору”. - Харків, 17-18 квітня 2013 р. - С. 293.

Надійшла до редколегії 25.11.2020

Схвалена до друку 05.01.2021

\section{Відомості про авторів:}

Леушин Сергій Геннадійович

старший викладач кафедри

Харківського національного університету

Повітряних Сил ім. І. Кожедуба,

Харків, Україна

https://orcid.org/0000-0003-0345-588X

\section{Бссова Оксана Василівна}

кандидат технічних наук

старший науковий співробітник

Харківського національного університету

Повітряних Сил ім. І. Кожедуба,

Харків, Україна

https://orcid.org/0000-0001-7744-1339

\section{Олешук Микола Миколайович}

Заступник командира військової частини А 2533 , Дніпро, Україна

https://orcid.org/0000-0001-9737-6896

\section{Information about the authors:}

\author{
Serhiy Leushyn \\ Senior Instructor \\ of Ivan Kozhedub \\ Kharkiv National Air Force University, \\ Kharkiv, Ukraine \\ https://orcid.org/0000-0003-0345-588X
}

\author{
Oksana Biesova \\ Candidate of Technical Sciences \\ Senior Research \\ of Ivan Kozhedub \\ Kharkiv National Air Force University, \\ Kharkiv, Ukraine \\ https://orcid.org/0000-0001-7744-1339
}

\section{Mykola Oleschuk}

Deputy Head of the Military Unit A 2533, Dnipro, Ukraine

https://orcid.org/0000-0001-9737-6896

\section{ЭКСПЕРИМЕНТАЛЬНЫЕ ИССЛЕДОВАНИЯ НЕУМЫШЛЕННЫХ АКТИВНЫХ ПОМЕХ ДЛЯ ПРИЧЕРНОМОРСКОГО РЕГИОНА, ИСТОЧНИКИ КОТОРЫХ НАХОДЯТСЯ ЗА ГРАНИЦЕЙ РАДИОГОРИЗОНТА В ДЕЦИМЕТРОВОМ ДИАПАЗОНЕ ВОЛН}

С.Г. Леушин, О.В. Бесова, М.М. Олещук

Исследование физических процессов над акваториями морей свидетельствуют о том, что изменения климата увеличивают вероятность появления ТРВ над морем. Поэтому возрастает вероятность появления АП, которые действуют за предель радиогоризонта. Прочессы, происходящие в прибрежных районах и над морем нестационарные, поэтому параметры АП, которые действуют за пределами радиогоризонта, существенно меняются. Однако при этом возрастает влияние непреднамеренных активных помех (АП), источник которых находится за чертой радиогоризонта. Причиной этого считают состояние радиофизических характеристик тропосферы над морской поверхностью. Экспериментальные исследования, проведенные в ХНУПС позволили получить характеристики непреднамеренных АП, которые могут возникать при существовании ТРВ. Опыт эксплуатации РЛС, расположенных вблизи Черного и Азовского морей показывает, что дальность распространения электромагнитных волн (ЭМВ) при наличии ТРВ может существенно превышать дальность по радиогоризонту. Для каждой РЛС ЭМС определяется отдельно. Поэтому необходимо исследовать АП для каждой позищии РЛС приморского размещения.

Ключевые слова: непреднамеренные активные помехи, тропосферный радиоволновод, экспериментальные исследования. 
EXPERIMENTAL STUDIES OF UNINTENTIONAL ACTIVE INTERFERENCES FOR THE BLACK SEA REGION, THE SOURCES OF WHICH ARE BEYOND THE RADIUTIONORIS

S. Leushyn, O. Biesova, M. Oleschuk

Studies of physical processes over the waters of the sea show that climate change increases the likelihood of TRH over the sea. Therefore, the probability of occurrence of AP operating outside the radio horizon increases. The processes occurring in coastal areas and over the sea are non-stationary, so the parameters of the AP, which operate outside the radio horizon, change significantly. However, this increases the influence of unintentional active interference (AP), the source of which goes beyond the radio horizon. The reason for this is considered to be the state of radiophysical characteristics of the troposphere above the sea surface. Experimental studies conducted in KhNUPS allowed to obtain the characteristics of unintentional AP, which can occur in the presence of TRH. Experience in the operation of radars located near the Black and Azov Seas and shows that the range of electromagnetic waves (EMC) in the presence of TRH can significantly exceed the range relative to the radio horizon. EMC is determined separately for each radar. Therefore, it is necessary to investigate the AP for each position of the radar coastal location. Turkish and Bulgarian broadcasting stations operating in the frequency range from $100 \mathrm{MHz}$ to $1 \mathrm{GHz}$ and located on the Black Sea coast, opposite the location of the agro-industrial complex, were selected as sources of active interference extending beyond the radio horizon. The work of such radio centers around the clock (in most cases), which allows us to celebrate the appearance of TRH. Sources of AP radiation are far beyond the line of sight $350 \ldots 601(\mathrm{~km})$ and it is impossible to explain such range of EMC propagation by traditional mechanisms. Abnormally long range of EMC propagation beyond the horizon is possible in the presence of TRH. The results of an experimental study of unintentional active interference (AP) in the Black Sea region for the decimeter range of electromagnetic waves (EMC) are presented.

Keywords: unintentional active interference, tropospheric radio waveguide, experimental researches. 